\title{
MOŽNOSTI VYTVOŘENÍ SKLADOVÉ SÍTĚ V LOGISTICE POSLEDNÍ MÍLE
}

\section{OPTIONS FOR CREATING A WAREHOUSE NETWORK IN THE LAST MILE LOGISTICS}

\author{
Nina Kudláčková1, , Miroslav Němec²
}

\begin{abstract}
Abstrakt
Moderní logistická praxe směruje ke komplexnímu řešení problémů a plné integraci dodavatelských řetězců. Jednou z oblastí, ve které je třeba nalézt efektivní řešení je vytvoření skladové sítě. Nalezení vhodného modelu pro umist'ování distribučních, respektive skladovacích center, který by kromě hlediska úspory nákladů či maximalizace zisku, zohledňoval také časové hledisko, může vést kzískání konkurenční výhody. Aplikace takového modelu na podmínky současných trendů voblasti logistiky poslední míle by pak mohla vést nejen k získání konkurenční výhody, ale také k získání většího podílu na trhu. Cílem tohoto článku je tedy prozkoumat možnosti využití stávajících metod a modelů, používaných pro vytvoření distribuční sítě, jako jsou metody statické, u kterých je možné sklady či střediska obsluhy rozmístit podle účelové funkce, a dle jejich povahy lze použít modely spojité, diskrétní či sít'ové. Dále jsou pak v článku zkoumány možnosti využití modelů dynamických, které jsou více zaměřeny na faktor času a mohly by tak být využity k alokaci skladủ či distribučních center, mimo jiné, také v logistice poslední míle, nebot' současným trendem je právě hledisko časové, kdy společnosti v současné době usilují o co největší zkrácení dodacích lhůt. Článek se věnuje možnostem využití lokačně-alokačních úloh, P-median modelu, Weberova modelu či pojetí problému umístění skladu jako nedimenzovaného problému umístění zařízení. Jako problematické se u výše zmíněných modelů ukazuje fakt, že tyto modely neberou v potaz zákazníky a prínos pro zákazníky. Je tedy třeba se zaměřit na nalezení takového modelu, který by bral v potaz určité prvky zákaznického servisu, jako je například snadná dostupnost produktů, frekvence dodávek či požadavky na čas dodání, a to nejen v př́padě logistiky poslední míle. Ze zkoumaných metod se jako nejlepší pro tyto účely jeví logistická metoda, popisovaná v češtině jako „Dům kvality“, jejímž účelem je zapracovat požadavky koncových zákazníků do finálního produktu společnosti, spolu s metodou známou jako „Analytický hierarchický proces“, jejímž cílem je rozklad složité nestrukturované situace na jednodušší komponenty, a „Analytický sítový proces", což je jedna z obecnějších metod „Analytického hierarchického procesu, zaměřená na sítové rozhodovací problémy s cílem určit optimální místo pro umístění zařízení. Cílem tohoto článku je prozkoumat možnosti využití kombinace výše zmíněných modelů pro rozmístění skladů či distribučních center v logistice poslední míle.
\end{abstract}

Klíčová slova globální logistika, distribuční centrum, dodavatelsko-odběratelský řetězec, modelování, lokační úlohy, logistika poslední míle

Summary Modern logistics practice aims at comprehensive problem solving and full integration of supply chains. One of the areas in which an effective solution needs to be found is the creation of a warehouse network. Finding a suitable model for the location of distribution or storage centers, which would, in addition to cost savings or profit maximization, also take into account the time aspect, can lead to gaining a

\footnotetext{
${ }^{1}$ Univerzita Pardubice, Dopravní fakulta Jana Pernera, Katedra dopravního managementu, marketingu a logistiky, Studentská 95, 53210, Pardubice, Česká republika

2 Správa a údržba silnic Pardubického kraje, Doubravice 98, 53353 Pardubice, Česká republika
} 
competitive advantage. Applying such a model to the conditions of current trends in the field of last mile logistics could then lead not only to gaining a competitive advantage, but also to gaining a larger market share. The aim of this article is to explore the possibilities of using existing methods and models used to create a distribution network, such as static methods, in which warehouses or service centers can be distributed according to purpose, and according to their nature can use continuous, discrete or network models. Furthermore, the article examines the possibilities of using dynamic models, which are more focused on the time factor and could be used to allocate warehouses or distribution centers, among other things, in last minute logistics, because the current trend is the time aspect of when companies they are currently working to reduce delivery times as much as possible. The article deals with possibilities of using location-allocation problem, P-median model, Weber's model, or the concept of the problem of warehouse location as non-dimensioned problem of equipment location. The fact that these models do not take into account customers and benefits for customers proves to be problematic with the above-mentioned models. It is therefore necessary to focus on finding a model that takes into account certain elements of customer service, such as easy product availability, delivery frequency or delivery time requirements, not only in the case of last mile logistics. From above mentioned methods, based on the time factor, the best for the deployment of distribution centers appears to be a combination of logistics method Quality function deployment (QFD), which allows to incorporate customer requirements into the final product in combination with the method Analytic network process. Unstructured situations on simpler components, possibly with the Analytic hierarchy process method, focused on network decision problems in order to determine the optimal location for the warehouse or distribution center. The aim of this article is to explore the possibilities of using a combination of the above models for the deployment of warehouses or distribution centers in last mile logistics.

Keywords global logistics, distribution centre, supply chain, modelling, location tasks, last mile logistics

\section{1 ÚVOD}

Úspěch či neúspěch skladovacích zařízení, at' už se jedná o soukromá či veřejná, závisí do značné míry na jejich umístění.

Výběr vhodné lokality pro umístění skladu nebo distribučního centra je jednou z nejdůležitějších součástí manažerského rozhodování, protože má přímý vliv na efektivní řízení dodavatelsko-odběratelských řetězců.

Čím efektivněji jsou dodavatelsko-odběratelské řetězce řízen, tím větší je šance společnosti na zlepšení logistických procesů a vdůsledku toho pak na zvýšení zisku, optimalizaci nákladů vynaložených v souvislosti s distribučními sítěmi a v neposlední řadě také na úroveň zákaznického servisu.

Důležitou roli v rámci efektivního řízení dodavatelsko-odběratelských řetězců tak hraje nejen množství, velikost a umístění distribučních center, ale také rozhodnutí o tom, ze kterého distribučního centra bude obsluhován který okruh spotřebitelů zákazníků.

Ještě donedávna byl na většině světových trhů využíván model, ve kterém byly výrobní distribuční kanály umíst'ovány na několik strategických pozic, přičemž hlavními faktory, ovlivňujícími toto rozdělení byly zejména vhodné lokace a výše vynaložených nákladů, tedy hledisko geografické, respektive finanční. Jinak řečeno společnosti se ubíraly směrem snižování nákladů v celém dodavatelsko-odběratelském řetězci, a současně usilovaly o co největší zkrácení dodacích lhůt.

Jelikož je problematika umíst'ování skladovacích zařízení, respektive distribučních center, z hlediska managementu záležitostí strategickou, kterou je třeba řešit na strategické úrovni, směřovaly snahy zejména k vytvoření optimální logistické sítě, která bude vyhovovat potřebám společnosti a zároveň bude schopná plně uspokojit mezinárodní charakter distribučních systémů s ohledem na globalizační trendy.

Jako jeden z hlavních globalizačních trendů je možné označit logistiku poslední míle, respektive požadavky na doručení ve stejný den. Logistika poslední míle představuje v současné době jeden z nejnákladnějších aspektů celého dodavatelsko-odběratelského řetězce. Logistika poslední míle totiž v současné době 
představuje výzvu zejména v oblasti udržitelnosti a reverzní logistiky. Co se udržitelnosti týče, je logistika poslední míle v současné době oblastí, kde je mnoho příležitostí pro nalezení úspor, at' už finančního nebo nefinančního charakteru. $V$ př́padě reverzní logistiky zde logistika poslední míle představuje možnost pro zákazníka produkt vrátit, takže logistika poslední míle se stále častěji stává logistikou první míle v případě reverzní logistiky.

Každopádně je v souvislosti s logistikou poslední míle zmínit důležitost kritéria času, které hraje v rámci zákaznického servisu zásadní roli, a v neposlední řadě také požadavky zákazníka na možnosti doručení a možnosti změn v doručení, což umožňuje mimo jiné také prudký vývoj „chytrých“ technologií např́íklad v oblasti sledování zásilky v reálném čase v rámci poslední míle. Rychlost doručení a př́stup k informacím v reálném čase, tedy možnost kontroly, se ukazují jako dva velmi důležité faktory, které ovlivňují vnímanou kvalitu zákazníkem.

\section{ROZHODOVÁNÍ O UMÍSTĚNÍ DISTRIBUČNÍHO CENTRA}

Jak uvádí Lambert, Stock a Ellram (2005), je při rozhodování o umístění skladu, respektive distribučního centra, důležité pečlivě zvážit a vhodně zvolit strategii, která bude pro jeho umístění použita.

Profesor Hoover (2018) ve své publikaci uvádí, že je možné využít v podstatě tři druhy strategií, založených na rozmíst’ování ekonomické aktivity. Jedná se o strategii orientovanou na trh, strategii orientovanou na výrobu a strategii středového umístění.

Podle Hoovera (2018) jsou při využití strategie orientované na trh sklady umíst'ovány v návaznosti na trh, tedy obvykle co nejblíže konečným zákazníkům. V tomto případě se jedná o strategii zaměřenou na maximalizaci úrovně zákaznického servisu. Společnost může v př́ípadě použití této strategie dosáhnou úspor nákladů při přepravě zboží prostřednictvím tzv. celovozových zásilek přímo z výrobních závodů nebo od dodavatelů či subdodavatelů do jednotlivých distribučních center či skladovacích zařízení.

Sklady umístěné v návaznosti na výrobu jsou pak podle Hoovera (2018) umíst'ovány do bezprostřední blízkosti dodavatelů, respektive výrobních zařízení. $V$ př́ípadě využití této strategie je kladen větší důraz na sdružování, respektive kompletování produktů pocházejících z odlišných dodavatelských zdrojů, než na vysokou úroveň zákaznického servisu.

Určitým kompromisem mezi dvěma výše zmíněnými strategiemi pak může být podle Hoovera (2018) využití strategie, kdy jsou sklady umístěné mezi výrobou a spotřebou, tedy zřizované v podstatě na půl cesty od výrobce ke konečným spotřebitelům. $V$ důsledku kompromisního řešení je pak také poskytovaná úroveň zákaznického servisu určitým kompromisem, nebot' je v případě této strategie obvykle vyšší než u skladů umístěných blí̌ze výrobě, zároveň však nižší, než u skladových zařízení umístěných blízko spotřebitelům.

Jak je uvedeno v Bílé knize Globálního institutu logistiky (2007), distribuční kanály jsou na globálních trzích většinou soustředěny do několika strategických pozic, bez ohledu na to, zda se jedná o umístění ve prospěch lokace či ve prospěch úspory nákladů. To znamená, že v minulosti bylo držení zásob naprosto běžnou záležitostí a bylo vnímáno jako hlavní funkce skladování, protože sklady byly budovány strategicky, pro dlouhodobé uskladňování produktů.

Z toho důvodu také problematika rozhodování o umístění distribučních center, respektive skladů, vycházela z kombinovaných teorií odborníků z oblasti ekonomické geografie. Mnohé z těchto teorií byly založeny právě na posouzení umístění z hlediska vzdálenosti a z hlediska nákladů.

\subsection{Modely rozhodování o umístění distribučního centra}

Jak uvádí Lambert, Stock a Ellram (2005), jednalo se zejména o Weberův model, Hooverův model, Model umístění v těžišti, Greenhutův model,. 
Lambert, Stock a Ellram (2005) uvádí, že Weberův model rozmístění skladových zařízení je založen na předpokladu minimalizace nákladů, a to tak, že za optimální pro umístění distribučního centra považuje takové místo, které umožňuje minimalizovat celkové přepravní, a tedy i logistické, náklady.

Podle Hoovera (2018) je však třeba při rozmist'ování ekonomických aktivit uvažovat kromě výše nákladů ze strany společnosti také faktory poptávky ze strany zákazníků. Model se tedy zakládá na předpokladu, že přepravní náklady nejsou lineárně úměrné vzdálenosti, tedy že náklady sice rostou s rostoucí vzdáleností, ovšem s klesajícím trendem. Tento klesající trend v oblasti nákladů tak při velkých dopravních vzdálenostech vede k rozhodování o umístění distribučních center, respektive skladů, spíše do koncových míst distribučního řetězce.

Norman a Greenhut (1992) ve svém modelu navazují jak na Webera, tak na Hoovera, ovšem uvažuje také faktory, jako prostředí, rentabilita či bezpečnost, tedy faktory specifické pro určitou společnost. Greenhutův model je tak založen na takovém umístění skladu, které umožňuje maximalizovat zisk společnosti.

Další možností pro modelování umístění distribučního centra, která je založena na měření přepravních nákladů je, jak uvádí Lambert, Stock a Ellram (2005), tzv. model umístění v těžišti, který určuje jako optimální místo umístění distribučního centra do takového místa, které umožní minimalizaci nákladů na přepravu produktů mezi výrobním závodem a trhem.

Všechny tyto modely kladou důraz na efektivní ŕízení dodavatelsko-odběratelských řetězců, tedy na počet, velikost a umístění distribučních center, respektive skladů. Důležité je však rozhodnout také o tom, které distribuční centrum bude obsluhovat které zákazníky, respektive okruhy zákazníků. Vytvoření modelu umístění distribučního centra lze tedy chápat také jako klasickou lokační úlohu a pro její řešení využít některou ze statických či dynamických metod operační analýzy.

\subsection{Využití lokačních úloh při rozhodování o umístění distribučního centra}

Jak uvádí Máca a Kalecký (2013), statické metody se zaměřují více na faktor prostorového rozmístění, u kterých musí být předem znám okruh zákazníků i jejich geografická poloha, stejně jako topografie prostoru, kde lze střediska obsluhy rozmístit podle účelové funkce. Podle jejich povahy pak můžeme rozlišovat modely spojité, diskrétní či sít’ové. Dynamické modely jsou pak zaměřeny více na faktor času.

Jak uvádí Nickel (2013), Weberův model byl vytvořen již počátkem 20. století ve snaze minimalizovat přepravní náklady, odvíjející se od lokalizace společnosti. V rámci modelu jsou definovány tzv. lokalizační faktory, kterými mohou být naleziště surovin, cena polotovarů či cena pracovní síly. Jedná se o typický prríklade úlohy s jedním střediskem obsluhy.

Účelová funkce pro optimální řešení těchto úloh je vyjádřena následující rovnicí:

$$
\min \mathrm{Z}=\sum_{\mathrm{i} \in \mathrm{F}} \mathrm{w}_{\mathrm{i}} \cdot \mathrm{d}\left(\mathrm{X}, \mathrm{P}_{\mathrm{i}}\right)
$$

Funkce umožňuje, podle Nickela (2013) minimalizovat celkové náklady Z, kdy množina všech poptávajících je označena $\mathrm{F}$ a váhy vzdáleností převedených na náklady zákazníka i jsou označeny $w_{i}$. X a $P_{i}$ a představují hledanou pozici obslužného střediska a danou pozici zákazníka i, takže $d\left(X, P_{i}\right)$ vyjadřuje vzdálenost mezi oběma místy.

Úlohu s jedním střediskem obsluhy lze, podle Nickela (2013), převést úpravou účelové funkce na úlohu $\mathrm{s}$ více středisky. Nový tvar funkce je pak zobrazen v následující rovnici:

$$
\min \quad Z=\sum_{i \in F} \sum_{j \in D} w_{i j} \cdot d\left(X_{j}, P_{i}\right)
$$


Jak uvádí Nickel (2013), množina všech poptávajících zákazníků je zde značena písmenem D, ohodnocená váha spojení mezi zákazníkem písmenem i a střediskem obsluhy j je potom $w_{i j}, d\left(X, P_{i}\right)$ je vzdálenost hledaného střediska obsluhy j a daného zákazníka i.

Rozšířením úlohy o ohodnocení váhy spojení mezi jednotlivými středisky obsluhy vznikne, podle Nickela (2013), následující rovnice účelové funkce, kde $v_{i k}$ označuje váhu mezi středisky obsluhy i a k.

$$
\min \quad Z=\sum_{i, k \in D, i<k} v_{i k} \cdot d\left(X_{i}, X_{k}\right) \sum_{i \in F} \sum_{j \in D} w_{i j} \cdot d\left(X_{j}, P_{i}\right)
$$

Lokačně-alokační úloha, podle Nickela (2013), přidává navíc k předchozím modelům obsluhy navíc ještě optimální přiřazení zákazníků, a to za předpokladu že jejich poptávka bude uspokojena.

Podle Nickela (2013) patří mezi další typy lokačně-alokačních úloh také úlohy kapacitní, ve kterých je rozmístění míst určených pro obsloužení zákazníků omezeno také kapacitou obslužného místa, náklady s tím spojenými, časovým hlediskem a dalšími faktory.

Obecně lze, podle Nickela (2013) modely diskrétních lokačních problémů rozdělit dle kapacitních omezení, tzn. podle limitů množství zboží, které může být vyrobeno, přepravováno či manipulováno z důvodů technicko-ekonomických (velikost výrobních strojů) anebo personálních. Rozlišují se modely tzv. bezkapacitní (nedimenzované), které zohledňují pouze bezvýznamné kapacity, nebo nesledují kapacity žádné, a modely tzv. kapacitní (dimenzované), které mohou být bud’ jednozdrojové (kdy poptávka je přiřazena danému zařízení) anebo vícezdrojové.

Z výše uvedených důvodů se Nickel (2013) domnívá, že problém umístění skladu lze popsat jako nedimenzovaný problém umístění zařízení, respektive distribučního centra či skladu.

Jak uvádí Cura (2010), nedimenzovaný problém umístění skladu je podle modelu Michela \&Van Hentenrycka definován jako sít' W + S uzlů a W.S spojnic uzlů, kde je počet S obchodů a počet W předpokládaných lokací na umístění skladů. Každý sklad má určité fixní náklady $f_{i} \geq 0$, a náklady na dopravu ze skladu i do obchodu j jsou označeny jako $c_{j i} \geq 0$. Úkolem je najít podmnožinu skladů a přiřazení skladů prodejnám tak, aby celkové fixní náklady a náklady na dopravu byly minimalizovány.

Tato úloha může být, jak uvádí Cura (2010) zjednodušena na pouhé nalezení podmnožiny skladů, kde každý obchod bude přiřazen k určitému skladu, a to k takovému, který znamená pro daný obchod dodání zboží s minimálními přepravními náklady. To znamená, že rozhodující proměnná $x_{i} \in\{0,1\} i=1, \ldots \ldots, W$ (12) znamená, že sklad i je otevřen pokud $x_{i}=1$ (11), a v opačném př́padě je zavřený.

Jak uvádí Özcan, Celebi a Sakir, matematický model pro řešení výše zmíněné úlohy může být vyjádřen následující rovnicí:

$$
\begin{gathered}
\min \sum_{i=1}^{W} f_{i} \cdot x_{i}+\sum_{j=1}^{S} \min \left[\left(1-x_{i}\right) \cdot M+\cdot c_{j i}\right] \\
\sum_{i=1}^{W} x_{i}=1 \\
x_{i} \in\{0,1\} i=1, \ldots \ldots, W
\end{gathered}
$$

M vyznačuje dostatečně velký počet tak, jako je např́klad $c_{\max }+1$. 
Jak uvádí Huifeng a Aigong (2008), je možné pro výběr umístění skladu a následné přidělení distribučního centra v určité ekonomické oblasti, která je charakteristická v určité míře jistou poptávkou i dodávkami od dodavatelů, možné využít také P-median model.

V tomto př́́padě je, jak uvádí Huifeng a Aigong (2008), analýza distribuční sítě pouze prvním krokem při výběru umístění centra a je třeba zásobovací počet stanic $\mathrm{P}$ je zvolit tak, aby uspokojil $\mathrm{n}$ poptávek z celkového počtu m zásobovacích stanic, za účelem minimalizace vzdálenosti, času nebo ceny. Předpokladem je poptávka i, kde $\omega_{\mathrm{i}}$ je množství (vážená hodnota) této poptávky i a $\mathrm{d}_{\mathrm{ij}}$ je vzdálenost mezi zásobovací stanicí j k poptávce i. Vzorec je následující (13):

$$
\min \left(\sum_{i=1}^{n} \sum_{j-1}^{m} \omega_{i} \cdot \alpha_{i j} \cdot d_{i j}\right)
$$

A současně

$$
\begin{aligned}
& \sum_{j=1}^{m} \alpha_{i j}=1, \quad i=1,2, \ldots, n \\
& \sum_{j=1}^{m}\left(\prod_{i-1}^{m} \alpha_{i j}\right)=P, \quad P \leq m \leq n
\end{aligned}
$$

$\alpha_{i j}$ je distribuční koeficient (14) a (15), který ř́ká, že pokud je poptávka i uspokojována zásobovací stanicí $\mathrm{j}$, je hodnota tohoto koeficientu 1, jinak nabývá hodnoty 0 . Vzorec je následující (16):

$$
\alpha_{i j}=\left\{\begin{array}{c}
1, \text { i je zásobováno prostřednictvím } j \\
0, \text { ostatní situace }
\end{array}\right.
$$

Nickel (2013) však upozorňuje, že tento model umístění skladu zahrnuje vždy pouze vybranou skupinu faktorů, přičemž na výběr aktuálního umístění skladu působí mnohem větší množství faktorů, jako jsou například kvalita poskytovaných služeb či požadavky zákazníků, které mohou výběr významně ovlivnit, a které tento model nezahrnuje.

Jak vyplývá z výše uvedeného, tradiční metody používané pro umístění distribučních center jsou v podstatě tři. Jedním z nich je stále přetrvávající a ve všech pádech skloňovaná minimalizace nákladů. Přístupy, které však používají minimalizaci nákladů za stěžejní kritérium, neodráží v žádném směru jakýmkoli způsobem zákazníky a přínos pro zákazníky. Jde tedy o přístup vycházející čistě ze společnosti a směřující k plnění jejích cílů.

Z tradičních modelů, řešících umístění distribučních center, vychází modely, které již určitým způsobem zahrnují do celého procesu zákazníky a jejich požadavky, nebot’ jsou založeny na maximalizaci zisku, respektive na rozdílu mezi ziskem od zákazníků a náklady na distribuční sít'. Opět zde není věnována dostatečná pozornost požadavkům zákazníka, nicméně tento model již bere vpotaz, že je to právě zákazník, kdo generuje společnosti zisk.

Jak uvádí Korpela, Lehmusvaara a Tuominen (2000), je možné v několika dalších modelech nalézt, kromě aspektů minimalizace nákladů či maximalizace zisku, také určité prvky zákaznického servisu, které jsou 
ve výsledku zahrnuty do návrhu umístění skladu. Jedná se například o dostupnost produktů, frekvenci dodávání či o požadavky na čas dodání.

Vzhledem $\mathrm{k}$ tomu, že vysoká úroveň nabízených služeb při distribuci zboží se stává jedním z nejdůležitějších prvků v konkurenčním boji se stala také z důvodu vývoje informačních technologií, je možné zavést do modelů další kvalitativní aspekty v řešení tohoto problému. Mezi tyto kvalitativní aspekty patři např. požadavky na zákaznický servis nebo zapojení vlastních př́stupů distributora do rozhodovacího procesu o umístění skladu. Došlo i ke zlepšení kvality a platnosti vstupních údajů, což umožňuje vyšší spolehlivost výsledků jednotlivých modelů.

\subsection{Současné trendy v rozhodování o umístění distribučního centra}

Jak uvádí Lukoszová a Stopka (2019), je problematika umístění distribučních center, respektive logistických center, v současné sobě vystavena velkému tlaku globalizačních trendů. Současný charakter dodavatelsko-odběratelských řetězců směruje spíše k obrátkovosti zásob a jejich rychlému přesunu napříč řetězcem, než k jejich dlouhodobému skladování. Do popředí zájmu se tak dostává požadavek na využití skladů pro pohyb, respektive rychlý přesun, produktů v síti. Společnosti jsou tak sice dále nastaveny v režimu snižování nákladů v celém dodavatelském řetězci, ovšem za současného tlaku na zkrácení dodacích lhůt. Ve svém důsledku to znamená, že si vpodstatě v současné situaci konkurují spíše dodavatelské řetězce než společnosti.

Problematika umístění skladu tak nabývá nových rozměrů, protože konkurenční výhodu lze v současné době získat pouze formou zákaznického př́stupu, tedy na základě poptávky upravovat strategii na jednotlivých trzích tak, aby odpovídala potřebám daného trhu, potažmo zákazníkům.

Jak uvádí Robinson (2018), dopravci čelí v současné době mnoha výzvám, pokud jde o úspěšné dodávání produktů koncovým zákazníkům. Nároky a očekávání spotřebitelů rostou a ukazuje se, že až 25 procent spotřebitelů je ochotno platit navíc za doručení ve stejný den. Lze předpokládat, že dodání ve stejný den tak dosáhne $25 \%$ podílu na trhu do roku 2025.

Nobis (2019), generální ředitel společnosti DHL pro Evropu, uvádí, že zákazníci se snaží v současné době získat svůj produkt rychleji, takže vzdálenost mezi spotřebiteli a produktem je třeba i nadále zmenšovat, což s sebou nese řadu problémů pro řadu lidí. Rozdíl mezi dodávkou ve stejný den a do druhého dne činí více než 24 a dává tak dodavateli velký manévrovací prostor. Zde je možné využít klasických modelů pro umístění distribučního centra, ze kterého je v průběhu 24 a více hodin možné obsloužit poměrně velké území.

Problém podle Nobise (2019) je, že není ekonomické, ekologické a v mnoha případech ani možné disponovat dvěma různými distribučními centry, respektive sklady, pro stejné zákazníky a jen jiný čas doručení. Největší výzvou je zde tedy být schopen řídit tyto dva kanály a dodávat produkty ze stejného umístění, jen s jinou časovou dotací. Zde je ovšem třeba zjistit, jaké položky by měly být k dispozici v rámci doručení ve stejný den a stěmi pracovat ve speciálním režimu. Jinými je třeba se dostat blíže k požadavkům zákazníků a zohlednit je při rozmist'ování distribučních center.

Zde ovšem nastává klasický akademický problém, množství skladovacích zařízení versus náklady. Známá křivka ve světě dodavatelského řetězce ukazuje počet skladovacích zařízení na jedné ose a náklady na straně druhé. Při zvyšování počtu zařízení se zvyšují náklady na zásoby, ale náklady na dopravu se snižují až do bodu, kdy opět začnou narůstat, právě v důsledku služeb jako jsou např́klad doručení ve stejný den zvýší. Úkolem je tedy také zjistit správný počet skladovacích míst, kde je možné dosáhnout nejvyššího snížení nákladů.

Také Abrams Kaplan (2020) uvádí, že aby dopravci měli šanci získat konkurenční výhodu, musí brát v úvahu základní trendy v tzv. logistice poslední míle a zaměřit se na požadavky zákazníků a kvalitu zákaznického servisu. Je tedy třeba nalézt takový model, který bude brát v potaz požadavky zákazníků. 
Jak uvádí Korpela, Lehmusvaara a Nisonen (2007) existuje model pro umístění distribučního centra či skladovacího zařízení, který bere v úvahu interní i externí kritéria ovlivňující výběr a podporující konkurenční výhodu. Model je založen na logistické metodě QFD (Quality function deployment), což se do češtiny překládá jako "Dům kvality". Jedná se o metodu, jejímž účelem je zapracovat požadavky koncových zákazníků do finálního produktu společnosti. Součástí metody je také řešení dle metody AHP (Analytic hierarchy proces), což se do češtiny překládá jako Analytický hierarchický proces - cílem této metody je rozklad složité nestrukturované situace na jednodušší komponenty, což umožní vytvořit hierarchický systém daného problému a ANP (Analytic network proces), což se do češtiny překládá jako Analytický sít'ový proces. Jedná se o obecnější metodu AHP, zaměřenou na sít’ové rozhodovací problémy s cílem určit optimální místo pro umístění zařízení.

Jak uvádí Mangan a Lalwani (2016), mnoho modelů vytvořených pro umístění skladu nereprezentuje důsledky závislosti kritérií. Většina metod multikriteriálního rozhodování je založena na konceptu možnosti přidání kritéria s předpokladem jeho nezávislosti. $V$ reálu však nelze prokázat, že jsou kritéria nezávislá, př́ípadně do jaké míry.

Jak uvádí Bals a Tate (2016) pro řešení vzájemné interakce jednotlivých prvků modelu byla odborníkem Saatym vytvořena metoda ANP (Analytic network proces), což se do češtiny překládá jako Analytický sít'ový proces. Jak bylo zmíněno již výše, jedná se o obecnější metodu AHP zaměřenou na sít'ové rozhodovací problémy.

Jak vyplývá z výše uvedeného, není možné v současných podmínkách využít stávajících modelů pro umístění distribučních center, nebot' nedorážejí současné požadavky zákazníků. $Z$ toho důvodu je třeba uvažovat o využití kombinace více metod multikriteriální analýzy. Jednak metodu, která umožní rozklad složité nestrukturované situace na jednodušší komponenty (například výše zmiňovaná metoda AHP, respektive ANP), jednak metodu, která umožní posuzovat technickou efektivitu produkčních jednotek systému na základě velkosti vstupů a výstupů, jakou je např́klad metoda DEA (Data Envelopment Analysis), což se do češtiny překládá jako metoda datových obalů.

Kombinace těchto dvou metod byla již v minulosti pro řešení rozhodovacích problémů využita, a to konkrétně například pro výběr pružného výrobního systému, či pro rozmístění výrobních závodů, kdy byly naměřené kvalitativní ukazatele váženy prostřednictvím AHP a následně byla použita metoda DEA k vyřešení vícekriteriálního problému rozmístění zařízení.

V jednom z dalších modelů Korpela, Lehmusvaara a Nisonen (2000) použili kombinaci těchto metod již př́mo pro skladové sítě, ovšem se zaměřením na operátora a jeho rozhodovací proces při výběru vhodného distribučního centra pro vyřízení dodávky. $V$ tomto případě bylo opět využito kombinace metod vícekriteriálního rozhodování AHP a DEA, model je tak založen na jejich vzájemné integraci. Koncepce modelu je v začlenění metody AHP již do procesu navrhování sítě tak, aby mohly být současně analyzovány požadavky jednotlivých zákazníků a jejich priority. Metoda AHP umožňuje vzít v úvahu kvalitativní i kvantitativní povahu kritérií a odvodit jejich jednotlivé priority. Metoda AHP je zde použita pro ohodnocení atributů zákaznického servisu a ostatních alternativních skladových operací, zatímco metoda DEA je použita pro nákladové faktory jako ohodnocení většiny nákladů a jejich efektivity. Zde je tedy prostor pro využití kombinace těchto metod pro vytvoření vhodného modelu. Otázkou je, zde je tento prostor také v oblasti zákaznického servisu, respektive v logistice poslední míle.

\section{SOUČASNÉ TRENDY V OBLASTI ZÁKAZNICKÉHO SERVISU}

Jak ve většině odborných publikacích v rámci teoretického základu, tak ve většině národních organizací v rámci praktické aplikace je na zákaznický servis nahlíženo jako na nedílnou součást logistického řetězce. Jedná se o činnost či funkcionalitu, kterou je třeba řídit, a to na všech úrovních, tedy od získávání zákazníků, přes vyřizování objednávek až po zpracování stížností zákazníků, případně reverzní logistiku. 
V praxi je třeba úroveň zákaznického servisu měřit, hodnotit a neustále vylepšovat, např́klad prostřednictvím aplikace Demingova cyklu.

Jak uvádí Lukoszová a Stopka (2019), neustálý rozvoj v oblasti mezinárodního obchodu a globální logistiky vede knutnosti úroveň zákaznického servisu neustále zlepšovat tak, aby umožnil společnosti získat konkurenční výhodu a umožnil tak upevnit její pozici na trhu národním. Zákaznický servis v tomto ohledu prošel v posledních deseti letech velkou proměnou, zejména v důsledku snadnějšího šíření negativních hodnocení a vedl u mnoha společností k tomu, že jej pojaly jako součást produktu, konkrétně tedy jako skutečný výkon o určitých parametrech, $\mathrm{v}$ současné době je to např́íklad schopnost vyexpedovat a doručit kompletní objednávku v režimu 24/7.

\subsection{Faktor času a zkracování dodací lhůty}

Obecným trendem nejen v globální logistice a v managementu dodavatelsko-odběratelských řetězců je výrazný tlak na faktor času.

Zkrácení dodací lhůty, respektive rychlost dodání produktů zákazníkovi je v současné době jedním z nejdůležitějších faktorů zákazníkem vnímané kvality, a to v podstatě ve všech tržních sektorech. Je to také možnost, jak získat konkurenční výhodu, a to nejen voblasti rychlosti dodání, ale také v oblasti rychlosti a pružnosti reakce na požadavky zákazníků.

Včasná reakce a v důsledku toho také zlepšení kvality zákaznického servisu, může vést $\mathrm{k}$ významnému navýšení tržního podílu a v důsledku toho také ke snížení požadavků na držení zásob, zlepšení kvality dodávaných produktů $\mathrm{v}$ důsledku redukce množství manipulací a době vystavení produktu fyzikálním a jiným vlivům, k rychlejšímu toku produktů dodavatelským řetězcem a v důsledku toho také ke snížení nákladů s tím souvisejících. Je tedy třeba pružně reagovat na vyvíjející se trh a změny v chování zákazníků. To předpokládá využití osvědčených postupů a technologií a jejich customizaci, neboli přizpůsobení produktů konkrétním požadavkům zákazníků. Základem je tedy poznat potřeby a přání zákazníků a následně umět na tyto potřeby správně a pružně reagovat.

Významným specifikem současné situace v oblasti customizace jsou pak také nové požadavky na způsob dodání produktů, tedy efekt, který svého času vyvolala společnost Amazon se svou nabídkou dodání do 48 hodin za velmi nízké ceny. Tomuto tržnímu trendu bylo následně nutné přizpůsobit řízení celého logistického řetězce. Mnoho společností se v současné době snaží o minimalizaci času dodání zboží k zákazníkovi s cílem získat konkurenční výhodu.

\subsection{Současné trendy v logistice poslední míle}

Mnoho odborníků věnuje v současné době svou pozornost logistice poslední míle, nebot' zde hraje faktor času významnou roli. Například Ploos van Amstel (2019) uvádí 7 největších trendů v logistice poslední míle. Abrahams Kaplan (2020) pak uvádí vlastní seznam devíti zásadních trendů v logistice poslední míle a Robinson (2018) pak hned deset zásadních trendů v logistice poslední míle. Trendy jednotlivých autorů mají svá specifika, na několika z nich se však autoři shodnou.

Podle Robinsona (2018) se v první řadě se jedná o možnosti, možnosti a další možnosti. Zákazníka prostě nelze přebít a v podstatě ani odbýt. Společnosti se musí přizpůsobit měnícím se požadavkům zákazníků, at' už na trzích B2C, B2B či dokonce C2C. Systémy dodávek do domu, dodávek v den objednání, časových oken, zpožděných dodávek, alternativních umístění produktů, bezpilotní stanice v kancelářích, sousedních obchodech a ve stanicích veřejné dopravy, procesy reverzní logistiky jako je vracení výrobků a obalů zaměřené na zákazníky a dodávky just-in-time, zkrátka všechno, na co si zákazník vzpomene, může (a ve své podstatě také musí) mít. To vede k vytváření více a více tzv. „touchpointů“ se zákazníky. A zákazníci chtějí služby lepší, možnost jejich sledování v reálném čase a s možností snadného získání prediktivních informací o skutečném dodání a př́ípadnou možností jeho odkladu. Jinými slovy zákazníci očekávají ne méně než $100 \%$ na time-in full-no error-no contact (OTIFNENC). Z výše zmíněných modelů však bere 
v potaz požadavky zákazníků pouze poslední z nich, tedy kombinace metod AHP, respektive její součásti ANP, a metody, která umožní posuzovat technickou efektivitu produkčních jednotek systému na základě velkosti vstupů a výstupů, jakou je např́klad metoda DEA. Je tedy možné v tomto případě kombinaci těchto metod pro plánování distribuční sítě v logistice poslední míle doporučit k využití, jelikož zohledňuje velké množství faktorů, a to jak ze strany společnosti, tak z pohledu zákaznického.

Dále Robinson (2018) uvádí, že jedním z trendů v logistice poslední míle je tzv. zapojení zákazníků. Společnosti by měly mít kontrolu nad náklady na doručení na úrovni jednotlivých zákazníků, jinými slovy mělo by být jasné, kteří zákazníci jsou klíčoví, respektive kteří z nich skutečně přinášejí společnosti zisk. Pokud by měly společnosti k dispozici informace o adresách zákazníků, mohly by využít jeden z výše uvedených modelů, případně jejich kombinaci, jak je navrhováno v předchozím odstavci tak, aby mohly pracovat na vytvoření alternativních distribučních bodů, respektive sítích těchto distribučních bodů a na rozšiřrených možnostech služeb logistiky a reverzní logistiky, modifikovaných přímo pro konkrétní oblasti. Lze zde tedy hovořit o jakési formě inteligentního outsourcingu a spolupráci, v případě bližší spolupráce pak dokonce i o dynamických cenách dodávek. $V$ případě konkrétních dodávek by tak mohli být zákazníci motivování $\mathrm{k}$ výběru nejúčinnější varianty z hlediska nákladů a společnost by pak mohla na základě zákaznických preferencí a za pomoci kombinace metod DEA a AHP vytvořit efektivní sít' distribučních bodů v rámci logistiky poslední míle tak, aby fungovala na principu win-win.

Ploos van Amstel (2019) pak zmiňuje jako jeden z trendů logistiky poslední míle využití partnerství veřejného a soukromého sektoru, a to formou vytvoření, respektive využití městských distribučních center a mikro center tak, aby logistika poslední míle byla co nejefektivnější, udržitelná a směřovala ke snižování externalit. Pro splnění požadavků zákazníků na okamžité doručení ve stejný den totiž roste trend, kdy společnosti budují nebo využívají městské skladové prostory, a to společně. Mnoho měst také v současné době rozvíjí nové obytné oblasti. To přináší jedinečné příležitosti k přepracování plánů těchto čtvrtí a využití jejich prostor pro potřeby nižší mobility, a tedy pro vytvoření sítě distribučních bodů, založené na kombinaci modelů AHP, respektive ANP a DEA tak, aby sít' fungovala efektivně jak z pohledu společnosti, tak z pohledu zákazníků.

Robinson (2018) také zmiňuje trend, ve kterém je kladen důraz na transparentnost v procesu dodání. Data, která obsahuje doklad o doručení spolu s informacemi o sledování, jsou neocenitelná, a to nejen v př́padě, kdy je zboží zpožděno, nebo se ztratí, ale také v př́ípadě, kdy je může společnost využít pro zlepšení zákaznického servisu. To by následně vedlo ke zvýšení spokojenosti zákazníků, protože by tak mohli získat přesné informace o tom, kde se jejich dodávka v současné době nachází, s realistickým odhadovaným časem jejího doručení a možností plánování a přizpůsobení dalších procesủ, to vše za pomoci moderních „chytrých“ technologií. Data, sbíraná prostřednictvím těchto nástrojů, by mohla být dále využita v rámci plánování a kontroly dodavatelského řetězce, kvality jednotlivých dodávek, časových a jiných úspor při vychystávání, tř́dění a dodávkách zásilek a v neposlední řadě při plánování distribučních center pro logistiku poslední míle, a to včetně již výše zmiňované reverzní logistiky. Inteligentní technologie mohou být navíc také využity například ke sledování zásilek citlivých na změnu teploty, což je obzvláště výhodné pro dodavatelský řetězec s řízenou teplotou. Také v případě tohoto trendu by bylo možné pro zbudování sítě skladovacích bodů, splňujících požadavky zákazníků i společnosti, možné využít výše zmiňovanou kombinaci metod AHP a DEA k dosažení optimálních výsledků a za dodržení podmínek udržitelnosti.

Z výše uvedeného je tedy zřejmé, že společnosti jsou nuceny v rámci zkvalitňování zákaznického servisu, odvíjející se od současných trendů vlogistice poslední míle sledovat a řídit celý cyklus objednávky. Rychlost a spolehlivost objednacího cyklu je ovšem vtomto př́padě ovlivněna nejen množstvím distribučních, respektive skladovacích center či bodů setkání, ale také úrovní držených zásob na těchto bodech distribuční sítě. To vše je třeba zohlednit a přiřadit $\mathrm{k}$ základním faktorům návrhu distribučního kanálu, potažmo i volby skladové sítě a přímého umístění skladu. Je tedy třeba znát nejen požadavky zákazníků na dodání zboží, ale také charakter samotného zboží tak, aby výše jeho zásob umožňovala nejen 
dodání $24 / 7$, ale také dodávky ve stejný den. Ke zbudování vhodné sítě distribučních center v rámci logistiky poslední míle by mohla být využita kombinace výše zmíněných metod AHP a DEA.

Kombinaci výše zmíněných metod by bylo možné využít také při plánování sítě skladovacích prostor na příklad pro zimní údržbu v rámci udržitelnosti silničního hospodářství.

\section{ZÁVĚR}

Problematika vytváření skladové sítě je obecně poměrně široká a nabízí celou škálu možných modelů, metod a úloh z oblasti operační analýzy. Současným trendem nejen v globální logistice a v managementu dodavatelsko-odběratelských řetězců je výrazný tlak na faktor času, tedy na zkracování dodacích lhůt jako požadavku ze strany zákazníka.

Zkrácení dodací lhůty, respektive rychlost dodání produktů zákazníkovi je v současné době jedním z nejdůležitějších faktorů zákazníkem vnímané kvality, a to v podstatě ve všech tržních sektorech. Je to tedy, mimo jiné, také možnost, jak získat konkurenční výhodu, a to nejen v oblasti rychlosti dodání, ale také v oblasti rychlosti a pružnosti reakce na měnící se a narůstající požadavky zákazníků. Z toho důvodu byl tento článek věnován zkoumání možností stávajících metod a modelů, používaných pro umístění distribučních, respektive skladovacích center, který by kromě hlediska úspory nákladů či maximalizace zisku, zohledňoval také časové hledisko. Aplikace takového modelu na podmínky současných trendů voblasti logistiky poslední míle by totiž umožňovala společnostem získání konkurenční výhody, a v důsledku toho také většího podílu na trhu.

V rámci zpracování článku tak byly zkoumány jak metody statické, u kterých je možné sklady či střediska obsluhy rozmístit podle účelové funkce, a dle jejich povahy lze použít modely spojité, diskrétní či sít'ové, tak modely dynamické, které jsou více zaměřeny na faktor času. V rámci zpracování článku byly zkoumány možnosti využití například lokačně-alokačních úloh, P-median modelu, Weberova modelu či nedimenzovaného problému umístění zařrizení, přičemž jako slabina u všech výše zmíněných modelů vyplynul fakt, že tyto model y v žádném směru nezohledňují požadavky zákazníků, př́nosy pro zákazníky, ani zákazníky jako takové. Bylo tedy třeba nalézt takový model případně kombinaci modelů, které by určité prvky zákaznického servisu zohledňovaly, a to nejen v př́padě logistiky poslední míle. Ze zkoumaných metod postupně vykrystalizovaly logistické metody, které umožňují zapracování jednoho, či více požadavků koncových zákazníků. Konkrétně se jedná o logistickou metodu, známou pod anglickou zkratkou QFD, což se do češtiny překládá jako „Dům kvality“ a samotná metoda je na kvalitu vnímanou zákazníkem také zaměřena, nebot' umožňuje zapracování požadavků koncových zákazníků do finálního produktu společnosti. Tento model je pak třeba kombinovat s jednou z dalších metod. Bud' se jedná o metodu, uváděnou pod anglickým názvem AHP, do češtiny překládanou jako Analytický hierarchický proces, která umožňuje rozklad složité nestrukturované situace na jednodušší komponenty, případně s metodou známou pod anglickou zkratkou ANP, což se do češtiny překládá jako Analytický sít’ový proces, což metoda, která se v rámci AHP metod zaměřuje na sít’ové rozhodovací problémy s cílem určit optimální místo pro umístění zařízení, založené na faktoru času a dalších faktorech, které mohou vyvstat jako požadavek od zákazníka.

Tyto metody, respektive jejich kombinace, již byly v minulosti v případě rozmístění distribučních center využity, ovšem ve všech př́padech se jednalo o zapracování požadavků ze strany společnosti, nikoli zákazníka. Cílem tohoto článku tak bylo prozkoumat možnosti využití kombinace výše zmíněných modelů pro rozmístění skladů či distribučních center v logistice poslední míle.

\section{Literatura}

Abrams Kaplan, D. 2020. Supply chain dive. 9 trends in last-mile delivery. Dostupné z: https://www.supplychaindive.com/news/last-mile-spotlight-trends-tech-gig-perfect/443091/ 
Bals, L., Tate, W. 2016. Implementing triple bottom line sustainability into global supply chains. Sheffield, UK: Greenleaf Publising.

Cura, T. 2010. A parallel local search approach to solving the uncapacitated warehouse location problem. Computers \& Industrial Engineering. 59(4), s. 1000-1009.

Hoover, E. M. 2018 The Location of Economic Activity. London: Sagwan Press.

Huifeng, J., Aigong, X. 2008. The Method of Warehouse Location Selection Based on GIS and Remote Sensing Images. Proceedings of the International Archives of the Photogrammetry, Remote Sensing and Spatial Information Sciences, XXXVII. Part B, 2(3), s. 545-548.

Korpela, J. Lehmusvaara, A., Tuominen, M. 2000. Warehouse operator selection by combining AHP and DEA methodologies. International Journal of Production Economics, 108(1-2), s. 135-142. [online]. Dostupné z: https://isiarticles.com/bundles/Article/pre/pdf/21008.pdf

Lambert, D. M., Stock, J. R. , ELLRAM, L. M. 2005. Logistika. 2. vyd. Brno: CP Books.

Lukoszová, X., Stopka, O 2019. Logistická centra na globálním trhu. Jesenice: Ekopress.

Máca, A., Kalecký, L. 2013. Lokačně-alokační úloha a centralita. Sborník Doktorské vědecké konference Think Together 2013. Praha: Česká zemědělská univerzita. s. 271-276.

Mangan, J. , Lalwani, Ch. 2016. Global logistics and supply chain management. Third edition. Chichester: Wiley.

Nickel, S. 2013. Location Theory - Discrete Location Problems. Facility Location and Strategic Supply Chain Management, Saarland University, Saarbrücken [online]. [cit. 2013-08-14]. Dostupné z: http://www.orl.unisaarland.de/Download/Dateien/Vorlesungen/FacilityLocationandStrategicSCM/Vorl esung.pdf

Nobis, A. 2019. Press Release: Bonn, 03/14/2019. Dostupné z: https://www.dhl.com/globalen/home/press/press-archive/2019/dhl-confirms-alberto-nobis-as-new-ceo-dhl-express-europe.html

Norman, G. , Greenhut, M. L. 1992. Conjectural Variations and Location Theory. Journal of Economic Surveys, 6(4), s.299-320.

Özcan, T. , Celebi, N. , Sakir, E. 2011. Comparative analysis of multi-criteria decision making methodologies and implementation of a warehouse location selection problem. Expert Systems with Applications. 38(8), s. 9773-9779.

Ploos van Amstel, W. 2019. What are the Top 7 Trends in Last Mile Logistics? Kennis DC Logistiek. [online]. [cit. 2013-08-14]. Dostupné z: https://www.kennisdclogistiek.nl/nieuws/the-future-of-last-miledelivery-10-most-important-trends

Robinson, A. 2018. Last Mile Logistics. [online]. [cit. 2013-08-14]. Dostupné z: https://cerasis.com/Last_Mile_Logistics.pdf

The Global Institute of Logistics. Globalization [online]. 2013 [cit. 2013-08-23]. Dostupné z: http://www.globeinst.org/research/collaboration-between-container-logisticsstakeholders/relationship_orientation_2007.pdf 